DOI: 10.20472/AHC.2020.006.001

\author{
NINA HABJAN \\ University of Tokyo, Japan
}

\title{
THE ‘ACT’ IN THE WORK OF KÔBÔ ABE AND FRANZ KAFKA
}

\begin{abstract}
:
This paper is an analysis of four literary works by the authors Kôbô Abe and Franz Kafka. Using the theory of the philosophy of action as the theoretical background, the paper explores the different acts the characters try to commit. Through the analysis of their action, the author of the article is trying to understand the motivation for the acts themselves, while also considering the wider social environment and how it might have affected the success or failure of the acts. The paper includes two of Abe's short stories, the first one being the story "Beyond the Curve", the English translation of which has been published in the collection by the same name and was translated by Juliet Winters Carpenter. The other short piece by Abe has not been translated to English as of yet, thus the English quotations of the work used in this paper will have been done by the author of the paper. The title of the story can be roughly translated as "The Raccoon dog of the Tower of Babel". The pieces by Kafka which are analyzed in the paper are "The Burrow" and "The Judgement". While the authors come from different sides of the planet, with different backgrounds and quite different influences, there are certain similarities in their approaches to the characters in their work. This paper explores to what degree the environment of the characters is to blame for their ultimate demise or victory, through the exploration of their willingness to act according to their own capabilities.
\end{abstract}

\section{Keywords:}

Literary analysis, philosophy of action, Franz Kafka, Kôbô Abe, act, Slavoj Žižek 


\section{Introduction}

This article is an attempt to analyze the way the two big world-known authors of the $20^{\text {th }}$ century portrayed their characters as active agents, committing different acts throughout their literary works. The main works analyzed are Franz Kafka's short stories "The Judgement" and "The Burrow", and Kôbô Abe's short stories "Beyond the Curve" and "The Raccoon Dog of the Tower of Babel". While both of Kafka's short stories have been translated to English and have been available to English-speaking readers for many decades, only one short story of Abe has been translated so far. Namely, "Beyond the Curve" which was published in a collection of stories of Kôbô Abe by the same name.

Abe and Kafka are two authors that have been frequently compared due to multiple similarities in the worlds created within their literary works and to the direct influence Kafka might have had on Abe's writing. It is important to notice, however, that even though these similarities do exist, the worlds of Abe and Kafka also include uncountable differences. This article is thus an attempt at exploring the different acts and actions of their characters, through which the ideas the authors might have wanted to share with their readers can be understood. While both authors also left many diaries, essay collections and other more personal writings which enable us to grasp the inner realities of the authors themselves, this article will mainly concentrate on the analysis of literary works themselves and leave the additional research of the authors' intention for a later time.

\section{Body of the article}

\subsection{What constitutes an "act"?}

As the first step of the analysis, a clear definition of an "act" is believed to be needed. As mentioned before, the definition and characteristics of an act as discussed in this article are borrowed from the field of the philosophy of action. This specific branch of philosophy defines an act as an activity which includes both the physical and the mental qualities (Arifuku, 1997). While on the one hand, an action is defined only as a physical activity, a physical movement, an act is an activity which is first planned by the person who commits the act - namely, the agent, and is later on carried out by that same agent.

Moreover, when we talk about the inner, psychological aspects of an act, the author of an introductory book on the philosophy of action Tetsuya Furuta (2013) explains, that a desire itself does not lead an individual towards carrying out an act. A desire of an individual to do something, such as a desire to eat watermelon one day, might not be a physical quality, but neither is it enough for an act to be committed. In order for an individual to commit an act, not only desire, but an actual intention is needed. An individual becomes an agent when he or she has an intention, which is the mental part of an act needed for the act to start existing. If we only feel the desire to eat watermelon, but do not have an intention of actually buying one and cutting it open, we might never commit the act of eating a watermelon. The example just given is a clear case of an intentional and conscious act on the behalf of an agent - one wishes to eat something, he has the intention of eating that specific something, so he acts towards acquiring that something, thus committing the act. 
On the other hand, Tetsuya Furuta (2013) explains that subconscious acts can also be perceived as acts. For example, our daily walk from our home to the bus or train station, or a drive towards the supermarket with our car, the types of acts we commit daily and during which we do not need to particularly concentrate to succeed in them. The only difference between any other act and these acts is the agent being used to committing the acts to the extent of carrying them out subconsciously.

Another important aspect of an act, is what Kôgaku Arifuku (1997) refers to as the correlation of an act. Whether an act can be carried out or not, also depends on the position of an individual trying to carry it out. Whether the act belongs to the individual who carries it out or not, depends on the influence this individual is under. For example, an act ordered by someone else is ultimately not the responsibility of the individual carrying it out and consequentially, that individual's "act" cannot be called a true act. Through this example we can see the close connection between philosophy of action and moral philosophy or ethics. The responsibility of the agent is an aspect which will not be closely touched upon in this article, however, as the article will mostly concentrate on the difficult situations, which the characters of different literary works find themselves in, and how the correlation of their acts is affecting the acts themselves.

\subsection{Previous Comparative Research on Abe and Kafka}

As mentioned before, Abe and Kafka have been comparatively researched due to the many similar motifs and themes used in their literary works. Influence of Kafka on Abe's work has also been noted by many researchers. Abe first came in contact with Kafka right after WWII, which is when the first Japanese translation of Kafka's literary works appeared. As the works of both authors is open to many interpretations due to the absurdity and bleak reality they might sometimes describe, Abe's work started regularly being described as "Kafkaesque". That is something Abe addressed many times throughout his career, as describing him simply as a "Kafkaesque" writer takes away a lot of the originality behind his work, making people see him merely a copy of the better-known writer. Japanese literary critic Kiichi Sasaki (2013a) sees the influence of Kafka in Abe's work as the main motivation for Abe's moving away from the strong influence of Rilke, and claims that Kafka's influence was of great importance in Abe's creation of his own literary world. According to Sasaki, he also moved away from the existentialist influences of Kafka soon thereafter, creating a reality that is different to that of Kafka's work.

Before getting into the analysis of the four literary works, I consider it important to shortly introduce the different aspects of comparison between the authors. Many researchers tended to find similarities between the dream-like narratives and absurd situations their characters find themselves in. For example, according to Hiroshi Yamanaka (1985), the situations which the characters of both Abe and Kafka's world are experiencing, appear all of a sudden and without any clear cause, making their experience even more tense, and causing the way out of them to be even more challenging. The uncertainty of the characters' situations and the ambiguous cause of their current position is also something that brings additional tension to the reader's experience. Another common point of both writers is also the use of metamorphosis of many of their characters as a reappearing motif. These metamorphoses are mainly shown as physical changes in the bodies of the characters, but in many cases also include an internal change in the personality of a character, which might be less noticeable to the reader. According to Yamanaka 
(1985), the cause for this internal fluctuation of different characters and their constant physical changes, lies in the uncertainty of boundaries between the things in the world of both authors. The boundaries between a subject and an object, for example, are not stable and constant anymore, as a result of which the characters are stuck in a world where even their physical appearance ceases to be certain, the result of which are the many physical metamorphoses of the main and side characters in both of their writings. Another common point Yamanaka (1985) notices in the writings of both Abe and Kafka, is the fact that neither's work brings the reader any type of a catharsis at the end. They might have perceived catharsis as a limitation of the author, as it limits the many possibilities of where the writing could go and what it could achieve.

Even though the authors are mostly compared due to the many common points their writing seems to have, some researchers also wrote on the differences. For example, Takahiro Arimura (1985) points out that Abe portrays characters, who suddenly wake up into existence. For example, the main character of "The Crime of S. Karma, who wakes up one day, realizing he doesn't remember his own name anymore, the realization which leads him on an unusual path down into self-discovery, or more likely down the path of losing oneself and one's identity completely. According to Arimura (1985) such characters of Abe suddenly notice the cracks in the reality they firmly believed in until that point. On the other hand, many of Kafka's characters are thrown into a world full of cracks, but they do not seem to notice them until the end. In Kafka's case, many of his characters blindly believe in their own right and in the system working correctly until their own demise. While many of Kafka's characters end up committing suicide, Abe's characters choose a slightly more positive ending in the world without many options. It can be said that they accept the challenge of living without a name, an identity or a memory, seeing it as a new opportunity to exist within the modern society. As Sasaki (2013a) points out, one of the main differences between the two writers is how the bottomless anxiety of Kafka's literary world transforms to a merely uncertain and anxious state of the character in the work of Abe, which often includes bizarre situations which end up appearing comical and ridiculous. Arimura (1985) also mentions the main difference between the two authors being Kafka's main characters' active attitude, while Abe's characters seem to be more passive. Arimura bases his thesis about these patterns on a comparative research of two stories, namely Kafka's "The Trial" and Abe's "The Crime of S. Karma". While the characters in these two literary works are indeed either extremely passive or overly active, it seems to be an overgeneralization to simply name all Kafka's characters as active and all Abe's characters as passive. Through an analysis of other works by the authors, I will try to show how Arimura's application of all of Abe's and Kafka's main characters to a certain pattern was a generalization on his part, and try to conduct a more detailed research concentrating on the acts of many of their main characters.

\subsection{The Analysis of "The Judgement" by Franz Kafka}

"The Judgement" is one of Kafka's earlier works written in the same period as one of his most well know stories "The Metamorphosis". More precisely, it was written on the night of the $22^{\text {nd }}$ September 1912 and finished within 10 hours. It was first published in the almanac of Kafka's friend Max Brod titled "Arkadia" in 1913.

The short story starts with the main character sitting by his desk, writing a letter to his friend who lives in St. Petersburg. He has been putting off writing to his friend about his engagement, as 
well as his success with the family business, as he feels his friend has been not had the best of luck in business lately, and writing about his own good news might make him feel even worse. After postponing it for long enough, however, Georg decides to finally write to his friend, the decision which he also announces to his father after entering his dark room to check up on him. His father's reaction to Georg's news is not what Georg would have imagined, however, as he asks Georg to stop lying about his friend from St. Petersburg, saying he very well knows the friend never existed. Throughout their interaction, Georg helps his father move onto the bed, as he is very weak. Georg's interpretation of his father's response is one of son caring for his elderly father; he knows his father's health has been deteriorating since his mother had passed away, which is also the reason why Georg himself started having a bigger role in the family business, feeling it is time to take over the duties of his father. The truth might not have been that simple, however. During their interaction Georg cannot ignore his father's big figure, which still towers over him even though he has grown weaker. As Georg tries to put his father into bed, his father, filled with anger lets Georg know that he remembers his friend well enough and had been writing letters to him on behalf of Georg, explaining everything. He blames Georg for having been overcome with his fiancée and forgetting about his good friend, as well as for forsaking his own mother after she had passed away, and orders Georg to die by drowning. Hearing his father's words, Georg runs out of the house and jumps off a bridge. At the same time, his father is described collapsing onto the bed.

The story ends with the main character 's suicide, which is a consequence of his father's direct order to do so. As mentioned previously, an "act" committed under a direct order cannot be named a true act, as the responsibility for it does not lie in the person committing the act, but in the person ordering it. Thus, it can easily be said that Georg Bendemann, the main character of this short story, takes a passive stance in contrast to his father's active stance. But in order to be able to say that the main character Georg Bendemann is portrayed as a truly passive character, we have to take a deeper look at his acts and actions.

If we turn to the analysis of Georg's final "act", the act of suicide, we have to include Žižek's thoughts on suicide as an act par excellence.

What is namely an act? Why is suicide an act par excellence? An act differs from an active intervention (action) in that it radically transforms its bearer (agent): the act is not simply something I "accomplish" - after an act, l'm literally "not the same as before." In this sense, we could say that the subject "undergoes" the act ("passes through" it) rather than "accomplishes" it: in it, the subject annihilated and subsequently reborn (or not), i.e. the act involves a kind of temporary eclipse, aphanisis, of the subject. (Žižek, 2008, p. 51)

Slovenian philosopher Slavoj Žižek writes about suicide as "an act par excellence", meaning a suicide committed willfully by the agent himself is a form of an internal transformation of the agent, making the agent somehow reborn, while also causing his demise. Suicide can work as an act of transformation, depending on the place within the character where it is coming from. As Žižek writes, "The greatness of an act depends strictly on the place from which it was accomplished”. (Žižek, 2008, p. 52) Considering Georg's suicide, however, we notice that it was 
not committed by his own will, but was ordered by his father, thus making it an act that does not belong to the agent himself. What would have been Georg's final "act" is thus transformed into a mere passive physical action. For Georg, there is no rebirth after his suicide and there is no salvation, his suicide is purely and solely his own demise.

The connection between Georg and his father is very important to their acts, however, which makes their stances as the active and the passive individual during an act shift constantly. If we turn back on the theory of Arifuku, describing one of the main characteristics of an act being its correlation, we can see how this correlation might function within the relationship of the father and the son in "The Judgement". We can say that their relationship is correlative, which means that when Georg is active, his father takes the passive stance, and other way around.

To explain how their relationship works, we have to get back to the beginning of the story. We are introduced to the main character as one who is satisfied with the way his life is going, and who thinks of himself as a lucky and successful businessman. Kafka writes:

Nun hatte aber Georg seit jener Zeit, so wie alles andere, auch sein Geschäft mit gröserer Entschlossenheit angepackt. Vielleicht hatte inn der Vater bei Lebzeiten der Mutter dadurch, daß er im Geschäft nur seine Ansicht gelten lassen wollte, an einer wirklichen eigenen Tätigkeit gehindert, vielleicht war der Vater seit dem Tode der Mutter, trotzdem er noch immer im Geschäft arbeitete, zurückhaltender geworden, vielleich spielten - was sogar sehr wahrscheinlich war - glückliche Zufälle eine weit wichtigere Rolle, jedenfalls aber hatte sich das Geschäft in diesen zwei Jahren ganz unerwartet entwickelt, das Personal hatte man verdoppeln müssen, der Umsatz hatte sich verfünffacht, ein weiterer Fortschritt stand zweifellos bevor. (Kafka, 1986a, p. 44 - 45)

The reader is thus introduced to Georg as an active and self-possessed character who has his fate in his own hands. Contrary to this opening image of Georg, however, the next passage, which is the passage in which Georg's father appears for the first time, makes us rethink the portrayal of Georg from the opening.

Sein schwerer Schlafrock öffnete sich im Gehen, die Enden umflatterten ihn $>$ Mein Vater ist noch immer ein Riese<, sagte sich Georg. (Kafka, 1986a, p. 43)

In this passage Georg seems almost surprised at the way his father still towers above him, making him feel smaller than he felt before. But then again, looking at his father, Georg cannot fail but notice how weakly he looks.

"Denk noch einmal nach, Vater", sagte Georg, hob den Vater vom Sessel und zog inm, wie er nun doch recht schwach dastand, den Schlafrock aus. (Kafka, 1986a, p. 49) 
The roles of the father and Georg keep on being overturned in the same way; noticing his father is weak, Georg starts feeling more powerful, only to have his father's strong presence make him step back.

It is also important to notice that even though the story has a third person omniscient narrator, so the narrator is not Georg himself, the reader sees into Georg's mind much more than into his father's. We thus get to understand Georg better and tend to empathize with his way of understanding and seeing the situation he is in. When he mentions that he is carrying his father to his bed by lifting him up under his armpits, we end up paying attention to the physical strength of Georg and not that much to the presence his father might be having in Georg's life. It is the passages in which Georg's father gets angry and screams at Georg, that we truly notice his importance and his full presence.

"Nein!" rief der Vater, daß die Antwort an die Frage stieß, warf die Decke zurück mit einer Kraft, daß sie einen Augenblick im Fluge sich ganz entfaltete, und stand aufrecht im Bett. (Kafka, 1986a, p. 50)

I have mentioned the correlative relationship between Georg and his father, but Takahashi points out another important detail we have to keep in mind when we are analyzing their connection. As Takahashi (2003) points out, the moment Georg enters his father's room, he has already lost the battle with his father. Waiting on Georg in his room, waiting for him almost as if setting a trap for him as he enters the room, the father has had the upper hand in their relationship right from the start. The shifting relationship between the two is thus a predetermined one - Georg was not going to win, he was not going to survive as long as his father was present in his life. It can be said that if Georg's suicide was to be stopped, it could only have been stopped by a change in their relationship, which was not possible. The order Georg's father gives to Georg is "und darum wisse: 'Ich verurteile dich jetzt zun Tode des Ertrinkens!' Georg fühlte sich aus dem Zimmer gejagt, trug er noch in den Ohren davon" (Kafka, 1986a, p. 53). It is this order that effects the main character almost like a spell. Within Georg the option of resistance does not exist; he is under a spell of his father's order and has no other choice but to follow it.

While Georg's physical strength acts in his favor, his words abandon him in presence of his father. When his father unleashes all of his anger on Georg, Georg in return becomes unable to defend himself against his father. Berman writes:

For all of Kafka's own linguistic precision, Georg is frequently unable to control his speech. Language gets the better of him, or remains beyond his grasp, sometimes erratic, sometimes recalcitrant, but never fully under his control. Without an effective command of language, he is hardly in a position to argue his own case. (Berman, 2002, p. 95)

As Berman explains, language remains beyond the grasp of Georg and becomes just another point for his father's superiority. If we look at Georg's final words to his father after he has given Georg the order, his words do not show any resistance. 
Liebe Eltern, ich habe euch doch immer geliebt. (Kafka, 1986a, p. 53)

As mentioned before, the Georg we meet in the opening sequence of the story is introduced to the reader as an independent individual. Reading on, however, we notice that might not have been the case.

Georg's initial self-absorption has hardly led to a genuine independence. On the contrary, the isolated autonomy of the beginning is nothing more than the beginning of the end for the weak individual, complicitous in a condition of universal alienation. Hence not only his incapacity to defend himself with argument but his obedient acceptance of the verdict. (Berman, 2002, p. 97)

Another important characteristic of Kafka's stories is also the namelessness of his characters. They are often identified with their jobs, meaning their jobs decide their roles inside the society. While this can be definitely said about many of his main characters, it stands true for his side characters as well. On one hand, these types of coded, symbolized characters, are somewhat universal in a way that due to their non-particularity they can easily be empathized with. On the other hand, however, the characters equaled and identified with their jobs serve their role of the robotized nation, where every individual is only a mechanism of the society as a whole. They appear to be brainwashed irrelevant of the reality they are "awakened" into. Arimura (1985) calls the fact that Kafka's characters are not "awakened into" the "conscience of existence" one of the main two crimes of his main characters, but it seems that the realities most of Kafka's characters belong to, are realities of different "un-awakened" states. The mechanized robot-like characters cannot be said to belong to the same world as the main character, yet neither are they "awakened" into the "conscience of existence". As mentioned before, Arimura sees Kafka's characters as characters that actively resist their situations. Sasaki (2013b), however, does not agree with that. He sees Josef K.'s constant visits to court as his obedience, and not his defiance. Josef $\mathrm{K}$. is not committing any acts appearing at the court, he is merely following instructions. More important than the reasons why the characters are not defiant, however, appears to be the fact that all their defiance is always suppressed. No matter whether the reality of Josef $\mathrm{K}$. is different to that of the other characters, they are all living in a society where defiance is not only suppressed, it is impossible.

Going back to "The Judgement", we notice that Georg's death equals the death of his father. This shows that the connection between the two characters, the active and the passive sides, can only exist with both of them present. That is why it can be said that everything that happens in "The Judgement" is closely related to the relationship between the two main characters. Due to his father's existence, Georg does not, and cannot resist until his very end. While Arimura stated that Kafka's characters are very active, "The Judgement" shows an overly passive character of Kafka, one who tries to stand up to his father, but fails miserably. 


\subsection{The Analysis of "The Burrow" by Franz Kafka}

The next analysis concentrates on Kafka's later short story titled "The Burrow". It was written between the years 1923 and 1924, when Kafka was suffering severely from tuberculosis and is unfinished. It was first published in a collection titled "Beim Bau der Chinesischen Mauer" in 1931 by Max Brod.

The plot of "The Burrow" is very simple and can be said to not include many acts. It is written in first person, but the reader never finds what kind of a creature the main protagonist is. We know it is an underground being similar to a mole, but even more important than the true form of the protagonist, are its actions and (failed) acts. This protagonist starts the story by telling the reader of the burrow it has built. It is immensely proud of it and it seems as if its whole life is circling around this creation. It is, however, not completely satisfied with its creation. Full of regrets, it explains how it should have worked harder in the past, acknowledging that its creation can never truly be completed. At one point of the story, the protagonist also leaves the burrow to observe it from the outside. It is paranoidly thinking someone might try to discover the burrow from the outside, so it acts as its own guard of this creation, but at the same time it realizes that once leaving the burrow to observe it from the outside, it is not able to enter it again. Full of anxiety it stays outside for a longer time than it originally planned, until it suddenly enters the hole feeling completely defeated and tired and falls asleep inside. The story gets more complicated when the character starts hearing a high-pitched sound coming closer every moment. Our protagonist knows this sound must be the sound of another creature, endlessly digging a hole which would lead straight to the protagonist, and act which would end in a fight between the two and the possible demise of the protagonist. This appearance of the unknown "other" in the story throws the protagonist into a series of regretful thoughts and reminiscences, during which we find out details about the acts the protagonist had in mind in the past, but which for one reason or the other never got to be actualized. The story abruptly ends before the other creature reaches our protagonist. Our protagonist does, however, decide to nervously but determinedly start digging a hole, whilst regretting not having prepared for an attack of another creature, which it knew might have happened at some point in the future. The last sentence of the story is "Wenn es mich aber gehört hätte, hätte doch auch ich etwas davon bemerken müssen, es hätte doch wenigstens in der Arbeit öfters innehalten müssen und horchen. - Aber alles blieb unverändert.--". (Kafka, 1986b, p. 165)

It can be said that in the case of "The Burrow", the narrator becomes active when it gets in contact with "the other", the invader. It does appear to be active before the story starts, but throughout the story itself its actions are small and irrelevant. The only big act of the story can be said to be its endless digging at the end, which can be seen as its act of defiance. However, it is a pointless act. The creature realizes the pointlessness of this last act, but this realization is not enough to stop it from doing it. It regrets not being more active throughout its life, so its last act is the definite act, namely Žižek's "act par exellence". It is a suicidal act, as the act of digging will not change the outcome for the protagonist. As a result, we can say that while the protagonist does have a passive stance in the previous failed acts, this final act of defiance is its active side actualized.

Moreover, as noted before, many of his failed "acts" are introduced to the reader through the inner thoughts of the narrator. Many of these "acts" are failed, as it only thinks of them but can 
never truly fulfill them. For example, it thinks of preparing for an invasion of another creature, yet it never does. Our protagonist feels a fear even when within its precious burrow that is supposed to protect it from the outside world.

Ich muß die sofortige Auslaufmöglichkeit haben, kann ich denn trotz aller Wachsamkeit nicht von ganz unerwarteter Seite angegriffen werden? Ich lebe im Innersten meines Hauses in Frieden und inzwischen bohrt sich langsam und still der Gegner von irgendwoher an mich heran. (Kafka, 1986b, p. $132-133$ )

We also find out that not all of these acts have failed; while it did become unable to return to the burrow one it left it, there are descriptions of other acts the protagonist actively took upon itself. We find out that in order to create the burrow, the protagonist hit its forehead against the wall a few hundred, even thousand times. But contrary to this extreme act, the acts the reader witnesses during the course of the story are not impressive in any way. Thus, it can be said that the protagonist becomes more active only after the invader appears. The invader has the active role in this duo, but in order to win over it, the protagonist has to become the more active one. Due to "The Burrow" being an unfinished literary work, the narrator might appear to be endlessly active, as the story has no ending and it suddenly ends with the protagonist's tireless digging. However, irrelevant of the work's non-existent ending, the stance and readiness of the narrator show the reader what its purpose is. Once the invader appears in the story, the protagonist becomes incredibly indecisive and nervous. It starts with the process of digging a hole. As it explains:

Ich beginne die Untersuchung, aber es gelingt mir nicht, die Stelle, wo man eingreifen müßte, zu finden, ich mache zwar einige Grabungen, aber nur aufs Geratewohl; natürlich ergibt sich so nichts und die große Arbeit des Grabens und die noch größere des Zuschüttens und Ausgleichens ist vergeblich. Ich komme gar nicht dem Ort des Geräuches näher, immer unverändert dünn klingt es in regelmäßigen Pausen. (Kafka, 1986b, p. 150)

The protagonist itself realizes the pointlessness of this act, as it cannot even decide on one single place to dig in, but instead nervously digs in different places. It explains, "Das wäre die notwendige Arbeit, für die es, nebenbei gesagt, natürlich viel zu spät ist, aber die notwendige Arbeit wäre es" (Kafka, 1986b, p. 158). However pointless the act must be, the protagonist knows what it must do. When listening to the other creature to hear any signs of it stopping its approach, the protagonist notices that this "other" does not take a break during night or daytime (Kafka, 1986b). Contrary to this unstoppable creature, however, looking back at its own life, the creature regrets all the times it rested when it should have been working.

Da geschah es, daß ich einmal in der Arbeitspause - ich habe in meinem Leben immer zu viel Arbeitspausen gemacht - zwischen meinen Erdhaufen lag und plötzlich ein Geräusch in der Ferne hörte. (Kafka, 1986b, p.143) 
It is through this comparison with the other creature that the protagonist notices its own mistakes. This comparison leads the protagonist towards its final act - if it becomes the active part of the battle that is to ensue, it will surely overcome the other creature, making it passive and lose the fight. Contrary to Georg, the final stance the protagonist of "The Burrow" takes is not passive. Koelb writes:

There is, after all, little more to the life of this creature than its building activity. The story is exclusively concerned with the burrow, its construction, and its properties. We know nothing about the narrator apart from stray hints that come in the course of his discussion of the structure. (Koelb, 2002, p. $350-351$ )

This safe haven the protagonist has created for itself, can be said to be its own salvation while also being its demise. The safety it provides suddenly makes it afraid of losing this newly found safety. As the protagonist itself puts it, the times of eating the food provisions it had prepared for itself are "Glückliche, aber gefährliche Zeiten". (Kafka, 1986b, p. 137)

The protagonist continues with its pointless working into endlessness, tirelessly defying the undefiable. The fear of the unknown and the other is a big topic of the 20th century arts, and Kafka's "The Burrow" is a good example of its usage in literature. It can be said that the otherness is needed to create the activity of the main character, as it is needed for the narrator to start its final act. Thus, the existence of the other is confirming the existence of the narrator, while it is simultaneously pushing the narrator's state of being into uncertainty. This story shows a different side of Kafka's characters than "The Judgement" does. They are not only either fully active or fully passive, but have their own wishes and intentions, some of which they manage to realize while others remain failed or un-attempted until the end.

\subsection{The Analysis of "The Raccoon Dog of the Tower of Babel” by Kôbô Abe}

"The Raccoon Dog of the Tower of Babel" was first published in a collection of Abe's stories titled "Kabe", meaning "The Wall" in 1951. The collection is divided into 3 parts, the first one being the named after the only story it includes, "The Crime of S. Karma", similarly the second part is named after the only story included in it, "The Raccoon Dog of the Tower of Babel", and the third part entitled "The Red Cocoon", consisting of four shorter stories, "The Red Cocoon", "The Flood", "The Magical Chalk" and "The Project".

The plot of the second part, which includes the story the analysis of which will be conducted in this article, is severely complicated. It is a story with a first-person narrator named K. Anten. In the opening of the story, the protagonist calls himself a "poet" and continues to write down different ideas and thoughts he comes up with by sitting on a bench in a park while observing the legs of the women passing by. It is in that moment that the protagonist notices a suspiciouslooking creature within the bushes, and proceeds to get his shadow taken by this creature, that turns out to be a raccoon dog, or a Japanese "tanuki". The raccoon dog itself was created by the main character's naming of the notebook into which he writes his poetic ideas. He names the notebook "The Skin of the Uncaught Raccoon Dog", and it is this process of naming the notebook 
that creates the shadow-stealing raccoon dog. The raccoon dog is thus a physical actualization of the act of naming by the protagonist.

The story continues with the main character becoming invisible as a consequence of his shadow's disappearance, with only his eyeballs remaining, floating in the air. He is taken to the Tower of Babel, where a series of ridiculous events ensue, during which the protagonist realizes that after his eyeballs get taken to the "eyeball bank", he will stop existing in his physical form completely and turn into vapor, disintegrating into air. It is then that the protagonist finally starts resisting the raccoon dog, which he blindly followed until that point even though he was not sure where the situation was going. Until this point the protagonist felt like the raccoon dog's will was stronger than his, which also coincided with the raccoon dog's own claims that it knew what the protagonist wished for even better than the protagonist himself did, as he is the direct creation of protagonist's poetic spirit. The protagonist manages to get his physicality back by using a time machine, which had been physically realized, like the racoon dog, based on the very idea the protagonist had written in his poetic notebook. The story ends with the protagonist being transported back into the moment in time when he was sitting on the bench in the park. He proceeds to chase away the approaching racoon dog by throwing stones and his notebook at it. The raccoon dog picks up the notebook and disappears into the bushes, and it is in this moment that the protagonist ceases to be a poet.

Firstly, it is important to discuss the act of naming, as the raccoon dog from the title itself is created and comes into the existence due to the main character's process of naming a notebook. Before discussing "naming" as an act, however, we have to ask ourselves whether we truly can call "naming" or "giving a name" an act. An act has to include a physical and a mental side in order to exist as an act. An act also requires the agent's knowledge or belief that the act can be carried out, as well as an intention. That being said, it cannot be claimed that our main character is writing his ideas and plans down with a clear purpose. He doesn't have a wish (or that wish cannot be said to have been implied directly) while writing, he is only writing things down due to his poetic nature. As he doesn't have a concrete wish, we cannot claim that his writing and naming are something the character believes in. However, not knowing where his action/act will lead him, the character still goes through with naming and writing, thus conducting the action/act. On the other hand, the character, as a poet, feels that his ideas and his name-giving, does have an intention. Whether that intention is the ideas physically coming true, or his own personal poetic intention of writing and naming things in order to remember them, we are not to say. But his action, is in fact an act, as it does include an intention, even though it's not the intention of what follows directly as a consequence of his act, and it also includes a physical result, the racoon dog itself. Is the act of naming then a spontaneous act, committed independently, irrelevant to whether the agent is participating or not? That cannot be claimed to be true either. Our narrator does consciously name the notebook and he does consciously write his ideas down, so the act can only come from him as an agent, whether he had a wish, knowledge and belief, or not. Abe (1998) himself has often written that naming things makes the reality easier for humans to perceive. By naming things, we "conquer" our reality, make it submissive to ourselves. "Naming" is one of the concepts authors of the 20th century, including Abe, have been dealing with. According to him, 20th century literature has to rethink our trust in language (Abe, 1974). What Abe explores throughout this story, however, is the fact that naming things does not immediately make the world clear and submissive to us. Comparing one of his earlier works to one of his later 
ones might show us how his ideas regarding language have developed. Naming of things is not only apparent in this story, it is also apparent in other Abe stories, such as "The Woman in the Dunes", where the main character wishes to name a new type of an insect in order to have his name remembered forever. In "The Raccoon Dog of the Tower of Babel", our character also directly implies that giving a scientific name to the creation of his Frankenstein monster-like raccoon dog would make others understand his situation and empathize with him (Abe, 1997a).

Abe shows internally torn individuals and their torn identities very visually through his novels, using metaphors and symbols to show their situations to the reader. For example, the identity of the main character S. Karma from "The Crime of S. Karma" is clearly torn between the private identity of the main character who forgets his name, and his life-size business card, which represents his public self. In the case of this story, however, the one character does not simply portray the public identity while the other would portray the private one. Having lost his physicality when he lost his shadow, our narrator becomes less himself than the raccoon dog.

All my actions and words are the embodiment of your wishes. My words are more truthtful to you, than even your own mood is. Trust me. [...] I ate your shadow, I digested it, and became more yourself than you. [...] I'm your will, your actions, your lust, your reason for being. (Abe, 1997a, p. 466)

The raccoon dog claims he is the physical side of the narrator, as well as his psychological side, as he knows everything the narrator is thinking and feeling. While the narrator still obtains some of his psyche, he has lost his physical self, thus the two literally represent the two sides of an act, the physical and the psychological one. As it digested the shadow of the protagonist, the raccoon dog finally gained all aspects of its physicality, became able to speak and grab things. He becomes the agent who can commit acts, as the protagonist himself does not have a body to serve him anymore.

I'm a raccoon dog brought up by you. [...] Having eaten the shadow, I finally became a full-fledged being. I became able to speak, and so my fingers grew longer and I became able to grasp objects with my hand. (Abe, 1997a, p. 465 466)

Hearing the raccoon dog's self-assured preaching, the protagonist stars to feel his will becoming weaker.

Like a sleepwalker, like a robot, I felt as if its words had begun to control my muscles. (Abe, 1997a, p. 471)

However, while the racoon dog keeps on saying how he knows everything the narrator is thinking, the story proves his claim to be a mere fabrication. He might have been right in some cases, but the protagonist still keeps some of his own activity and will, thus managing to confront the raccoon dog and resist him. The protagonist realizes, that as long as he keeps his eyeballs, 
which represent his last physical body, he can resist. The first appearance of his resistance is when the narrator screams "NO!" as a response to the raccoon dog saying the narrator has no right to choose anymore (Abe,1997a, p. 482 - 483). While the narrator can feel his will growing weaker and is falling into the persuasive traps set for him by the raccoon dog, he still manages to resist. This scream is the first big act of resistance the narrator was capable of doing. It is at this point that the narrator notices the lies the raccoon dog had been feeding him, and realizes his own power.

The second time the narrator resists by screaming, is when he is told his eyeballs will be taken by the eyeball bank, and this second resistance can be said to show his own unwillingness to part with the last part of his physical self (Abe, 1997a). In the end, it is through the usage of his own plans and ideas, basically through his own poetic nature, that the protagonist manages to win over the raccoon dog. He uses the time machine he had created by naming it and writing its name down into his notebook, and goes back in time. What caused the initial loss of his own physicality, solves the problem as well. That is, the products of the act of naming done by the narrator. If the burrow in "The Burrow" is both a calming place and the cause of the narrator's panic, the ideas the narrator of this story writes down in his notebook are the cause of his initial demise and the reason for his revival in the end. There is always an active and a passive participant in an act, and while the raccoon dog was active in the beginning, once the narrator becomes more active, the raccoon dog has no other choice but to step back.

The loss of his shadow is thus something that does not only show the internal division in the narrator, it also causes the narrator to act defiantly. The active raccoon dog is the activity having escaped from the narrator himself, which the narrator has to reclaim by becoming active himself, thus eliminating the raccoon dog. Moreover, the narrator's resistance can be said to be double-folded. First point is the resistance/defiance itself, as the active part of the narrator. He runs away from the raccoon dog, hides in the confusing rooms of the tower of Babel, steals the creature which functions as a time-machine and manages to escape back into the past. The second one, however, is the result of the defiance itself, namely the denial of the narrator himself. As the raccoon dog is a part of the narrator himself, denying him means the narrator's own selfdenial. At the end of the story, he throws his own notebook at the raccoon dog, thus losing his notebook, which is the fulfillment of all of his plans and ideas. He throws away his own poetic part of himself, thus losing a part of himself. The protagonist being a poet is one of the first things the reader finds out as he begins to read it, and the ending which concludes that the narrator has ceased to be a poet is thus of great importance.

As mentioned before, our protagonist, the "poet", stares at women's legs as they pass by, observing them and being inspired by them he writes down the ideas into his notebook. For his poetic self, his vision is thus of essential value. In one passage at the beginning of the story, the protagonist feels calmed by staring at the night sky through his binoculars. He describes the feeling of existing solely through his own sight as a joyful and free feeling (Abe, 1997a). It is important to notice that the name of the protagonist itself might also give us a clue about how important his own sight was to him. His name "K. Anten" is similar to the Japanese word "kanten", meaning "point of view".

On the other hand, one's sight, or more precisely, one's eyeballs are harmful to the raccoon dogs. A character named Jehovah, the God of Israel in the Hebrew Bible, who is in charge of accepting the protagonist's eyeballs into the eyeball bank, explains: 
Eyeballs are harmful to both the raccoon dogs and myself. Human eyes burn us like concentrated sulfuric acid. [...] I used to be horrified by human eyes. I tried to avoid them by proclaiming that whoever saw Jehovah would die, but humans were no longer fooled by that. (Abe, 1997a, p. 484)

As the protagonist loses his physical form, he notices that he feels overjoyed by the fact that he can no longer be seen by the others. Being invisible makes him the ultimate observer.

The feeling of losing my physicality made me feel as if I had escaped anxiety. There is no denying that it made me remember the feeling of joy one feels when one unconsciously erases one's physical body. (Abe, 1997a, p. 464)

However, the joy the protagonist feels as he becomes invisible is something the raccoon dog knew would happen from before. As it points out, the way the protagonist had been observing the legs of the passing women in the park, he must have wished to be invisible so the women would defenselessly walk in front of him. (Abe, 1997a, p. 467)

This story, however complicated and absurd in its events, has the narrator as a poet at its center. The narrator uses his poetic spirit to come up with different poetic ideas, which he writes down into his notebook. He does not seem to realize, however, his own capabilities as a poet. His act of writing down his ideas and naming the creations he comes up with, are acts with physical results, which in the case of this story is the creation of the raccoon dog. Although a creation of the poet, the raccoon dog wants to become the poet himself, thus eliminating the narrator and becoming a full-fledged being. The raccoon dog becomes active and manages to create acts all of a sudden, because it is not purely an animal, but the narrator himself in another form. What ensues is a sort of a competition between the two forms of the narrator, and as they are identical in a way that they represent the same protagonist, his internal and external being in different forms, their acts are correlative. Meaning, that when one of them is active, the other one has no other choice but to be active. Their relationship shifts similarly to that of Georg and his father, with the difference that in this story, our protagonist wins. He wins at a loss, as he is bound to abandon a part of himself, but it is this last act of defiance which defines him as the active agent of the story.

\subsection{The Analysis of "Beyond the Curve" by Kôbô Abe}

"Beyond the Curve" is a short story that was first published in 1966 in the magazine "Chûôkôron". It was later expanded into a full-length novel entitled "The Ruined Map" in the English translation, or "Moetsukita Chizu" in the Japanese original. The story starts with the protagonist walking up a hill when suddenly realizing that he does not exactly know where he is heading, nor who he is. He remembers a town at the other side of the hill, but he cannot be sure if the town is something he had made up or not. This realization causes him great anxiety. He is horrified and unable to walk up and over the hill, as he is afraid of the consequences of the 
possibility that the view on the other side of the hill is not what he remembers it to be. Soon thereafter he also realizes that he does not remember his own name. Instead of walking up the hill, he enters a café at the bottom of it. He notices the waitress working there and keeps on exchanging glances with her. Trying to find any clues as to who and where he is, he takes all of his possessions out of his pockets and analyzes them. He finds a business card with a phone number written on its back, a triangular badge, a book of matches and a piece of paper that looked like a small sketch or a map. He tries to call the phone number from the phone in the café, but no matter how many times he tries, the line is always busy. He notices the waitress smiling at him, and thinks of seducing her, but does not go through with it. He leaves the café, taking a cab across the hill. There is a town on the other side, a town much bigger than anything the protagonist might have imagined. He stops by another public phone and calls the previous phone number again, only to have the waitress of the café picking up. She tells him the money he has in his wallet was to pay for her rent, as well as that the business card belongs to his best friend, a cook at the café he entered. He decides to throw away all of the possessions he had found in his pocket, as he will not pursue his initial wish to try and remember more about his life. He accepts that he has not lost himself in the middle of that hill and has instead found himself.

In this story of Abe, the before-mentioned vision, one's sight, is of ultimate importance to the narrator. It can be said that his own existence is connected to his vision. Observation and "seeing" are usually active acts, not passive activities. The story of "Beyond the Curve" starts with our narrator not being able to remember the town beyond the curve. That is, the place where his home most probably is. He does see a solution to what appears to be a temporary memory lapse, however, in his own eyesight. If he could only see the town with his own eyes, he would remember everything.

Once l'd taken in the view with my own eyes I was sure the problem would settle itself, like a pill dislodged from the throat by a drink of water. (Abe, 1992, p. 227)

The narrator even connects the existence of the town itself with his eyesight and his memory, thinking that perhaps if he cannot see it nor remember it, then it must not exist.

Every image I held of what lay beyond the curve was fast disappearing, as if it were being wiped clean with a very efficient eraser. First colors, then silhouettes, and then forms, until it seemed the town's very existence would fade away and then vanish. (Abe, 1992, p. 226)

But as our narrator is closely connected to this unstable and non-existing town within his memory, his own identity also starts to shatter. He does not know who he is, nor what he looks like. It is important to notice, that he does not forget just any detail about his life, however. As he points out, he has had similar memory lapses before (Abe, 1992). This time, however, he forgets the town he is connected to, as the town that is so closely connected to his identity. A town where his home might be. 
In fact, my sense of familiarity with this place might not be based on a true memory but on a deceptive sense of déjà vu. In like manner, my assumption that I was on my way home might, logically, be a mere extension of the feeling. In which case, taking the thought to its logical conclusion, I myself was no longer me, but some mysterious other. (Abe, 1992, p. 227)

After entering a coffee shop. It is at this point that he realizes he has forgotten his own name as well.

It was true; I had forgotten my name. But as long as I remained convinced that I was myself, finding out what my name was should be easy once I set my mind to it. The elusive town at the top of the hill represented the contents of my life, but a name, however much you made of it, was no more than a registered mark. (Abe, 1992, p. 233)

As he sits in the café, he notices a waitress working there, with which he has many interactions. However, most of there were visual interactions, meaning they interacted with their eyes. The interactions include the protagonist's staring at the waitresses' legs, and her observation of his unusual behavior in the store (Abe, 1992).

Where the bus taillights had been, now the image of the woman was reflected. Part of a streetlight beyond the web of branches was superimposed on her face, so I couldn't be sure, but she appeared to be watching me. (Abe, 1992, p. 235)

These exchanges between the narrator and the waitress are very important when we talk about the act of seeing in this story. "Being seen" is somewhat more positively described in this story than it is in Abe's other stories. While it does make the narrator nervous when the waitress observes him, he becomes more active due to the looks he gets from her. He stares back at her, observing her from a distance (Abe, 1992). His seeing and being seen becomes his act. He decides to try to seduce the woman by making her understand the meaning of his look. He writes, "Now it was up to her to realize the purpose of my gaze and awaken to the role she had to play" (Abe, 1992, p. 238). Using his look as a form of seduction, will, in his mind, bring back his lost memories.

Abe commonly uses the motif of a physical transformation of characters to show their internal cracks in their personalities, not all of his transformations are necessarily physical. This short story includes a transformation of our main character which does not include his physical appearance. The narrator of "Beyond the Curve" transforms into a so-called "tabula rasa", not remembering anything connected to the formation of his identity and being again empty as a blank sheet. His transformation could be called an act if we consider the narrator's change to be conscious. He does not seem to have been aware of the pattern of actions he was following, walking down the street similarly to other characters, going to work every day with the same bus until the point when something inside him changed and he suddenly lost all the memory of the 
pattern itself. It can be said that even though the tedious everyday life was a part of his subconsciousness as it was completely automatic, the transformation was caused by the narrator's desire to break out of that repetition. Our narrator gets to a conclusion that he did not in fact lose his memory at the middle of the hill, but had in fact regained it. He did not lose himself, he has found himself for the very first time. He has awakened into Arimura's "conscience of existence". Even though our narrator forgets his name, which is a similar situation to the situation of S. Karma from "The Crime of S. Karma", the narrator's stance is different. He is not passive and letting the situation guide him, he himself chooses to not find his name, but instead begins a new life as a blank sheet without any memory holding him back. The restrained and patterned life he had led before, ceases to appear as something logical and "normal", and begins to feel twisted and unusual.

Maybe the sense of continuity I had had in front of that curve - the sense that everything up to then was normal - had itself been a strange dream. (Abe, "Beyond the Curve", pp. 247)

The sense of continuity he had felt his whole life was false, and the only thing that is not false, is what and where he is that very second. If he was thinking his life had a purpose, a goal, if he felt identified with himself, then all of those thoughts and feelings must have been a dream. Now he is a nobody, a person without a name, lost within a town he has no memory of. His new identity is nonexistent, as he continues to exist without the need for one. His active stance of observing and seeing has led him to accept his new circumstances and become this new unidentified person. While some researchers might see these types of Abe's characters as characters that passively accept their fate and give into the uncertainty of modern society, thus comparing them with Kafka's characters and their predetermined fates, the protagonist's stance which is described within this story is anything but negative. This world of uncertainty is a world of possibility for the protagonist, as he is no longer tied to a set identity. He has left the range of social rules and lives outside them. He is an active agent who does not only act according to his own will, he also begins to create his own rules.

\section{Conclusion}

While Abe was familiar with Kafka's works, his writing can be said to go into a completely different direction than Kafka's. Arimura might have seen Kafka's characters as active and Abe's as passive, but trying to apply all of their characters to a certain pattern ignores the importance of the actions and acts the characters achieve throughout their stories. While Abe does build on a similar world of robotized and alienated modern society, his modern world is not as oppressive, and does include a solution for the characters. In Abe's world, Georg's suicide is no longer needed and while the pointless act of the narrator of "The Burrow" might still not have a meaning, it does not need one any longer. Abe's world is a world in which an individual does not only stop following the rules of the society, he also does not feel lost nor prosecuted for it any longer. He instead continues his existence inside this endlessly growing city, as an unnamed, anonymous individual, one that does not feel any oppression by the society any longer. The stances of both of 
the authors' characters is expressed throughout the acts they commit. Fear in the presence of another and the consequential passive stance is present in many of the characters that appeared in the analyzed works. Namely, Georg of "The Judgement", the creature which appears as the protagonist in "The Burrow" and the protagonist of "The Raccoon Dog of the Tower of Babel", K. Anten. All of these characters have to find their way out of the situation they were thrown in, and it is their response in that exact situation which defines them most. While Kafka's characters were defined as active compared to Abe's, the two characters in stories analyzed in this article, are severely oppressed and have difficulties finding their way out. On the one hand, Georg does not even try to resist, resistance in his world does not even exist, while the creature of "The Burrow" seeks resistance even though it itself knows how it will end. On the other hand, we have the two protagonists of Abe's literary works. K. Anten follows the deceiving raccoon dog until his own demise is imminent, and it is in that moment that he finally decides to create his own fate and resist. In Abe's world, resistance is not impossible anymore. While resisting in a situation will not lead to the solution we would traditionally expect from a novel or a story, it will lead the character into a new direction which neither the characters neither us, the reader, could have expected. There is no happy ending in Abe's writing, as there is none in Kafka's, but the exploration of the $20^{\text {th }}$ century gentrified towns and the individuals living in them, leads us to the new solutions to the new problems that only a world as new as this one could have. Characters losing their names do not need to remember them anymore, as they live in a massive complex of endless buildings and businesses, they instead choose to melt within this enormous conglomerate that is the new city, and exist in their namelessness, as this is the ultimate freedom one can achieve within society.

\section{References}

Abe, K 1997a "Baberu No Tô No Tanuki”, in Abe Kôbô Zenshû 002, Shinchôsha, Tokyo, p. 452 - 491.

Abe, K 1992, "Beyond the Curve", trans. Juliet Winters Carpenter, in Beyond the Curve, Kodansha International, Tokyo, p. $223-247$.

Abe, K 1974, Hassô No Shûhen: Abe Kôbô Taidanshû, Shinchôsha, Tokyo.

Abe, K 1998, "Hihyôteki Kaidan", in Abe Kôbô Zenshû 011, Shinchôsha, Tokyo, p. 499 - 500.

Arifuku, K 1997, Kôi No Tetsugaku, Jôkyô Shuppan, Tokyo.

Arimura, T 1985, "Dai Go Shô Kafka To Abe Kôbô no Shôsetsu - 'Shinpan' To 'Kabe - S. Karuma Shi No Hanzai'", in Arimura T \& Yagi H (ed), Kafka To Gendai Nihon Bungaku, Dôgakusha, Tokyo, p. 145 -170 .

Berman, R A 2002, "Tradition and Betrayal in 'Das Urteil", in Rolleston J (ed.), A Companion to the Works of Franz Kafka, Camden House, pp. 85 - 99.

Furuta, T 2013, Sore Ha Watashi Ga Shita Koto Nano Ka: Kôi No Tetsugaku Nyûmon, Shinyôsha, Tokyo.

Kafka, F 1986a, "Der Bau”, in Brod M (ed.), Beschreibung eines Kampfes, S. Fischer Verlag, Frankfurt am Main, p. $132-165$.

Kafka, F 1986b, "Das Urteil”, in Brod M (ed.), Erzählungen, S. Fischer Verlag, Frankfurt am Main, p. 43 53. 
Koelb, C 2002, “Kafka Imagines His Readers: The Rhetoric of 'Josefine die Sängerin' and 'Der Bau', in Rolleston J (ed.), A Companion to the Works of Franz Kafka, Camden House, London, p. $347-359$.

Rolleston, James (ed.) 2002, Companion to the Works of Franz Kafka, Camden House, London.

Sasaki, K 2013a "IV Sengo No Sakka To Sakuhin - Abe Kôbô", in Furuichi M \& Fukushima N (ed.), Sasaki Kiichi Zenshû IV, Kawade Shobô Shinsha, Tokyo, p. 367 - 379.

Sasaki, K 2013b, “III Tôzai Hikaku Sakkaron - Franz Kafka 'Shinpan' To Abe Kôbô 'Kabe'”, in Furuichi M \& Fukushima N (ed.), Sasaki Kiichi Zenshû V, Kawade Shobô Shinsha, Tokyo, p. 280 - 288.

Takahashi, Y 2003, Hiraita Keishiki Toshite No Kafka Bungaku, Chôeisha, Tokyo.

Yamanaka, H 1985, "Dai Yon Shô Kafka to Abe Kôbô - Sono Jigazô, Teichaku to Ryûdô -“, in Arimura T \& Yagi H (ed.), Kafka To Gendai Nihon Bungaku, Dôgakusha, Tokyo, p.107 - 144.

Žižek, Slavoj 2008, Enjoy Your Symptom!, Routledge, New York. 